\title{
Authors response to correspondence regarding paper entitled Syphilitic hepatitis: a case report and review of the literature
}

\author{
Jiaofeng Huang ${ }^{1}$, Bo Wan ${ }^{2,3}$, Mingfang Wang ${ }^{1}$, Yueyong Zhu ${ }^{1}$ and Su Lin ${ }^{{ }^{*}}$ (])
}

\begin{abstract}
In the correspondence from Abdurrahman et al., they raised three main concerns and critiques of our recently published article entitled "Syphilitic hepatitis: a case report and review of the literature". First question pertains to the timing of dermatology opinion, second regarding the history of sexual exposure, and lastly regarding the treatment duration of syphilitic hepatitis. We thank the authors for their constructive comments and would like to answer these questions in detail.
\end{abstract}

Keywords: Syphilis, Hepatitis, Rashes

We appreciate the detailed review and commentary on our manuscript [1] from Abdurrahman et al. [2]. The first concern is regarding the timing of dermatology consult and syphilitic rashes. The patient described in our manuscript had two dermatology consultation. The first consult was at the local hospital when the rashes were noticed, and the second consult at our referral hospital upon admission. At both consultation with dermatologist, the opinion was that the rashes were secondary to an allergic reaction. The complete clinical examination of the genitals, palms and soles but did not reveal any skin lesions. Syphilitic rashes are known to occur in around $80 \%$ of patients with syphilitic hepatitis [3], and often present as multiple non-pruritic, erythematous, nonconfluent maculopapular lesions generally concentrated in the trunk, palms and soles of the feet. We agree with the authors that if the correct diagnosis of syphilitic hepatitis

This reply refers to the comment available online at https://doi.org/10.1186/ s12876-020-01496-5

*Correspondence: sumer5129@fjmu.edu.cn

${ }^{1}$ Department of Hepatology, Hepatology Research Institute, The First

Affiliated Hospital, Fujian Medical University, No. 20, Chazhong Road,

Taijiang District, Fuzhou 350001, Fujian, China

Full list of author information is available at the end of the article could have been made earlier, the invasive liver biopsy could have been avoided. This is precisely the reason why we decided to report this particular case.

Second, Abdurrahman et al. noted that we did not describe the patient's sexual history in detail, we agree with him on this point. In fact, the patient denied a history of unsafe sexual activity upon admission, which we duly stated in the manuscript. Interestingly, even after the syphilis infection was confirmed, patient still denied any history of unsafe sexual activity. However, even in the absence of a clear high risk sexual history, the antibody positivity was still powerful evidence of the diagnosis of Syphilis infection.

The third question Abdurrahman et al. raised is about the duration of antibiotics administered to patient for syphilitic hepatitis. The recommended duration of antibiotic administration is $2-4$ weeks [4]. The reported patient was discharged after the first dose of penicillin injection from our hospital. At the second follow-up visit, patient informed us that he has received a 2-month penicillin injection at a local clinic. We too concure with Abdurrahman et al. that the treatment duration of 2 months was too long and is problematic at multiple levels, however we recorded and reported the case-report as matter 
of fact. Prolonged duration of treatment however would not change the diagnosis of syphilitic hepatitis.

In conclusion, although there are some deficits and missing information in our case report, the diagnosis of syphilis is quite clear. This case highlights an atypical presentation of syphilitic hepatitis and and we hope that readers would get better insight into this rare disease.

\section{Acknowledgements}

We are very grateful to Abdurrahman et al. for the detailed evaluation of our article.

\section{Authors' contributions}

$\mathrm{JH}$ and SL wrote the primary draft. YZ, BW and MW made critical comments. All authors have read and approved the manuscript.

\section{Funding}

This work received no dedicated research funding.

\section{Availability of data and materials}

Not applicable.

\section{Ethics approval and consent to participate}

Not applicable.

\section{Consent for publication}

Not applicable.
Competing interests

All authors have no conflicts of interests to declare.

\section{Author details}

${ }^{1}$ Department of Hepatology, Hepatology Research Institute, The First Affiliated Hospital, Fujian Medical University, No. 20, Chazhong Road, Taijiang District, Fuzhou 350001, Fujian, China. ${ }^{2}$ Faculty of Life Sciences and Medicine, King's College London, London SE1 1UL, UK. ${ }^{3}$ Guy's and St Thomas' NHS Foundation Trust, London, UK.

Received: 20 July 2020 Accepted: 12 October 2020

Published online: 17 November 2020

\section{References}

1. Huang J, Lin S, Wang M, Wan B, Zhu Y. Syphilitic hepatitis: a case report and review of the literature. BMC Gastroenterol. 2019;19(1):191.

2. Kaya A, Kaya SY. Management of syphilitic hepatitis. BMC Gastroenterol. 2020. https://doi.org/10.1186/s12876-020-01496-5.

3. Huang J, Lin S, Wan B, Zhu Y. A systematic literature review of syphilitic hepatitis in adults. J Clin Transl Hepatol. 2018;6(3):306-9.

4. Ghanem K, Ram S, Rice P. The modern epidemic of syphilis. N Engl J Med. 2020;382(9):845-54.

\section{Publisher's Note}

Springer Nature remains neutral with regard to jurisdictional claims in published maps and institutional affiliations.
Ready to submit your research? Choose BMC and benefit from:

- fast, convenient online submission

- thorough peer review by experienced researchers in your field

- rapid publication on acceptance

- support for research data, including large and complex data types

- gold Open Access which fosters wider collaboration and increased citations

- maximum visibility for your research: over $100 \mathrm{M}$ website views per year

At BMC, research is always in progress.

Learn more biomedcentral.com/submissions 